\title{
Pengaruh Kompetensi Kepemimpinan, Budaya Organisasi terhadap Kinerja Pegawai di Universitas Negeri Manado
}

\author{
TINNEKE E.M. SUMUAL \\ Program Studi Manajemen, Fakultas Ekonomi Universitas Negeri Manado \\ email : tinnekesumual@gmail.com
}

\begin{abstract}
This study aimed to analyze the direct and indirect influence between leadership competencies, organizational culture on employee performance at the State University of Manado. The method used is survey data collection techniques using a questionnaire circulated to 79 employees of class II and III were taken by proportional random sampling technique. Data analysis using regression analysis techniques with Path Analysis models. The results showed that in total there are significant Leadership Competencies to employee performance through organizational culture at the State University of Manado .
\end{abstract}

Keywords: organizational culture, leadership competencies, performance employee

\begin{abstract}
Abstrak. Penelitian ini bertujuan untuk menganalisis pengaruh langsung dan tidak langsung antara kompetensi kepemimpinan, budaya organisasi terhadap kinerja pegawai di Universitas Negeri Manado. Metode penelitian yang digunakan adalah survey dengan teknik pengumpulan data menggunakan angket yang diedarkan kepada 79 pegawai golongan II dan III yang diambil dengan teknik Proporsional Random Sampling. Analisis Data menggunakan teknik analisis Regresi dengan model Path Analysis. Hasil penelitian menunjukkan bahwa secara total terdapat pengaruh Kompetensi Kepemimpinan terhadap kinerja pegawai melalui budaya organisasi di Universitas Negeri Manado.
\end{abstract}

Kata Kunci: budaya organisasi, kompetensi kepemimpinan, kinerja pegawai

\section{Pendahuluan}

Kedudukan dan peranan sumber daya manusia dalam organisasi memiliki posisi kunci bagi kemajuan dan keberhasilan organisasi. Peran yang sangat strategis dari sumber daya manusia semakin disadari oleh organisasi, modal organisasi yang tidak sekadar memberi kesuksesan dalam jangka pendek bagi organisasi tetapi akan mengembalikan nilai investasi untuk jangka panjang.

Pada organisasi Perguruan Tinggi, peran sumber daya manusia dalam hal ini pegawai (tenaga administrasi) tidak sekadar peran pembantu untuk mencapai tujuan organisasi tetapi disadari bahwa dukungan pegawai yang ditunjukkan melalui kinerjanya akan sangat membantu penyelenggaraan organisasi Peguruan Tinggi secara efektif dan efisien.

Universitas Negeri Manado (Unima) adalah salah satu Perguruan Tinggi Negeri di Sulawesi Utara yang ada sejak tahun 1955 dengan nama IKIP Manado dengan keadaan sumber daya manusia di tahun 2014 adalah 855 orang tenaga edukatif dan 416 orang pegawai. Unima memiliki areal lahan sekitar 300 ha dan dukungan kualitas tenaga edukatif yang semakin meningkat setiap tahun tetapi belum ditopang dengan pegawai yang kinerjanya mengarah pada visi dan misi lembaga.

Richard L Hughes, Robert C. Ginnett dan Gordon J. Curphy (2009: 370) menjelaskan bahwa

kinerja atau performance concerns those behaviors directed toward the organizations's mission or goals or products and services resulting from those behaviors.

Dengan demikian dapatlah dikatakan bahwa perilaku pegawai yang kurang mencerminkan visi, misi dan tujuan lembaga mengindikasikan kinerjanya masih rendah.

Received: 5 Januari 2015, Revision: 28 April 2015, Accepted: 25 Juni 2015

Print ISSN: 0215-8175; Online ISSN: 2303-2499. Copyright @ 2015. Published by Pusat Penerbitan Universitas (P2U) LPPM Unisba Terakreditasi SK Kemendikbud, No.040/P/2014, berlaku 18-02-2014 s.d 18-02-2019 
Kinerja yang rendah tidak hanya dilihat dari hasil kerja, tetapi juga dari proses sebagaimana konsep kinerja yang dijelaskan oleh Wibowo (2010: 2) bahwa kinerja memiliki makna yang luas, bukan hanya hasil kerja, tetapi termasuk bagaimana proses pekerjaan berlangsung. Kinerja adalah tentang melakukan pekerjaan dan hasil yang dicapai dari pekerjaan tersebut. Fenomena menunjukkan bahwa belum semua pegawai di Universitas Negeri Manado responsif terhadap penyelesaian tugas. Selain itu, proses pelayanan administrasi terlalu lama mengindikasikan bahwa ada permasalahan mengenai kinerja.

Kinerja pegawai tidak hanya dilihat dari hasil yang dikerjakan tetapi bagaimana perilaku dibalik kerja seseorang, sebagaimana dikemukakan oleh beberapa ahli yang dikutip Michael Amstrong (2009 : 30-31), sebagai berikut ini :

Performance is something that the person leaves behind and that exist apart from the purpose (Kane 1996). Performance should be defined as the outcomes of work because they provide the strongest linkage to the strategic golas of the organization, customer satisfaction and economic contribution (Bernadin et al (1995). Borman and Motowidlo (1993) put forward the notion of contextual performance that covers non-job-specific behaviors such as cooperation, dedication, enthusiasm and persistence and is difdferentiated from task performance covering jobspecific behaviors. As Fletcher (2001) mentions, contextual performance deals with attributes that go beyond as competence and that foster behaviors that enhance the climate and effectiveness of the organizations. Brumbah (1988) on performance means both behavior and results. Behaviors emanate from the performer and transform performance from abstraction to action. Not just the instruments for results, behaviors are also outcomes in their own right- the product of mental and physical effort applied to task- and can be judged apart from results Performance means both behavior and results. Behaviors emanate from the performer and transform performance from abstraction to action. Not just the instruments for results, behaviors are also outcomes in their own right- the product of mental and physical effort applied to task- and can be judged apart from results.

Setiap organisasi ingin agar sumber daya manusianya mencapai tingkat kinerja tinggi, sehubungan dengan itu diperlukan suatu ukuran tentang kinerja. Pengukuran perlu dilakukan untuk mengetahui apakah pelayanan yang diberikan sesuai standar yang ditentukan. Untuk mengukur kinerja yang bersifat pelayanan, menurut Wibowo (2010: 352) adalah:

(1) Productivity indicators, yaitu suatu indikator yang memfokuskan pada jumlah pekerjaan yang diselesaikan dalam jangka waktu yang telah ditentukan;

(2) Utilization rates, yaitu indicator yang menunjukkan jumlah jasa tersedia yang dipergunakan, seperti pada tingkat penempatan sekolah;

(3) Time targets, yaitu indicator yang menunjukkan rata-rata waktu yang diperlukan untuk menyelesaikan sejumlah pekerjaan, misalnya jumlah waktu yang diperlukan untuk menyelesaikan pesanan;

(4) Volume of services, misalnya jumlah perbaikan rumah yang diselesaikan;

(5) Demand/service provision, yaitu indikator yang menunjukkan seperti jumlah sekolah juru rawat dibandingkan jumlah penduduk anakanak.

Muya James Ng'ang'a dan Wesonga Justus Nyongesa (2012: 211-217) menjelaskan bahwa kinerja efektif dapat diukur dari:

1) How well we are doing; 2) If we are meeting our goals; 3) If our customers are satisfied; 4) If our processes are in statistical control; 5) If and where improvements are necessary.

Ada berbagai faktor yang memengaruhi kinerja pegawai, di antaranya adalah kompetensi Kepemimpinan. Pemimpin yang kompeten menjadi lebih muda menggiring pegawai memiliki kinerja yang mendukung tujuan organisasi. Palan (2007:5) menjelaskan competencies (kompetensi) adalah kecakapan dan keberdayaan yang merujuk pada keadaan atau kualitas mampu dan sesuai. Kompetensi di tempat kerja merujuk pada pengertian kecocokan seseorang dengan pekerjaannya.

Kompetensi merujuk kepada karakteristik yang mendasari perilaku yang menggambarkan motif, karakteristik pribadi (ciri khas), konsep diri, nilai-nilai, pengetahuan atau keahlian yang dibawa seseorang yang berkinerja unggul (superior performer) di tempat kerja. Wibowo (2010: 111-121) menjelaskan bahwa kompetensi berhubungan dengan apa yang dilakukan orang ditempat kerja pada berbagai tingkatan dan memperinci standar masing-masing tingkatan, mengindentifikasi karakteristik, pengetahuan dan keterampilan yang diperlukan oleh individual yang memungkinkan menjalankan tugas dan tanggung jawab secara efektif sehingga mencapai standar 
kualitas profesional dalam bekerja dan mencakup semua aspek catatan menajemen kinerja, keterampilan dan pengetahuan tertentu, sikap, komunikasi, aplikasi dan pengembangan.

Menurut strata kompetensi, ada 3 jenis kompetensi yaitu: (1) Core competencies. Merupakan kompetensi inti yang dihubungkan dengan strategi organisasi sehingga harus dimiliki oleh semua karyawan dalam organisasi; (2) Managerial competencies. Kompetensi yang mencerminkan aktivitas manajerial dan kinerja yang diperlukan dalam peran tertentu; (3) Functional competencies. Kompetensi yang menjelaskan tentang kemampuan peran tertentu yang diperlukan dan biasanya dihubungkan dengan keterampilan profesional atau teknis.

Perguruan tinggi di era sekarang ini memerlukan berbagai kompetensi kepemimpinan. Kompetensi kepemimpinan menurut Zenger \& Folkman (2002: 83)

as the combination of knowledge, skills, traits, and attributes that collectively enable someone to perform a given job. Penekanan pada aspek kemampuan dirinya sebagai seorang pemimpin dilihat dari penguasaan pengetahuan, keterampilan dan sifat-sifat pemimpin untuk mendukung pelaksanaan pekerjaan dapat memengaruhi peningkatan kinerja pegawai.

Konsep yang sama dengan menekankan pada kemampuan individual sebagai seorang pemimpin juga disampaikan oleh Josh Bersin (2007: 10) dengan mengatakan bahwa,

Leadership competencies are those which are used to assess an individual's ability and skills to be a leader or manager. Menurutnya, ada 4 kategori kompetensi kepemimpinan yaitu: (1) Execution (results); (2) Energy (passion and hard work); (3) Energize (ability to inspire others); and (4) Edge (ability to make tough decisions).

Kompetensi berkait dengan karakteristik individual yang potensial dari seorang pemimpin. Michael Zwell (2000: 18-138) mengemukakan kompetensi

as the enduring traits and characteristics that determine performance, sedangkan kompetensi kepemimpinan mencakup: (1) Visionary leadership; (2) Strategic thinking; (3) Entrepreneurial orientation; (4) Change Management; (5) Building organizational commitment; (6) Establishing focus.

Menurut Joko N.H(2005: 51-58), kompetensi tingkat manajer memerlukan aspek kompetensi sebagai berikut: (1) Flexibility; kemampuan mengubah struktur managerial; (2) Change implementation; kemampuan mengimplementasikan perubahan; (3) Interpersonal understanding; kemampuan untuk memahami nilai dari berbagai tipe individu; (4) Empowering ; kemampuan untuk melakukan pemberdayaan terhadap Sumber Daya Manusia.

Selain kompetensi kepemimpinan, faktor lain yang turut memengaruhi kinerja pegawai adalah budaya organisasi. Setiap organisasi termasuk perguruan tinggi, memiliki budaya organisasi yang berbeda-beda sehingga perbedaan budaya organisasi akan memengaruhi pegawai dalam perilaku kerjanya. Budaya organisasikan dimanifestasikan oleh Hall (1993: 607-618) dalam bentuk beliefs and assumptions, values, attitudes and behaviors of its members is a valuable source of firm's competitive.

Pandangan yang sama juga dikemukakan oleh Schermerhorn et. al (2011: 366) dengan mengutip pendapat Edgar Schein,

organizational or corporate culture is the system of shared actions, values, and beliefs that develops within an organization and guides the behavior of its culture.

Mc Shane \& Von Glinow (2010: 416419) mengemukakan budaya organisasi consists of the values and assumptions shared within an organization. Menurutnya dimensi dan karakteristik dari budaya organisasi dapat dilihat dari:

(1) Innovation: Experimenting, opportunity seeking, risk taking, few rules, low cautiousness; (2) Stability: Predictability, security, rule oriented; (3) Respect for people: Fairness, tolerance; (4) Outcome orientation: Actionoriented, high expectations, results-oriented; (5) Attention to detail: Precise, analytic; (6) Team orientation: Collaboration, peopleoriented; (7) Aggressiveness: Competitive, low emphasis on social responsibility.

Masalah kinerja pegawai menjadi menarik untuk diteliti karena dampaknya akan mengganggu kinerja organisasi secara berkelanjutan. Penelitian Komir Bastaman (2010) melihat bahwa kinerja pegawai di sekretariat Daerah Kabupaten Subang dipengaruhi oleh iklim komunikasi, kepuasan komunikasi dan komitment. Penelitian lainnya tentang kinerja guru dilakukan oleh Aan Komariah (2014) dengan mengkaji kepemimpinan transformasional, iklim sekolah, kinerja guru terhadap produktivitas sekolah. Pada objek dan faktor yang berbeda penelitian ini bertujuan untuk menganalisis pengaruh langsung dan tidak langsung antara kompetensi kepemimpinan, budaya organisasi terhadap kinerja pegawai di Universitas 
TINNEKE E. M SUMUAL. Pengaruh Kompetensi Kepemimpinan Budaya Organisasi terhadap Kinerja Pegawai ...

Negeri Manado.

\section{Metode Penelitian}

Penelitian ini menggunakan metode survei untuk memperoleh data tentang kinerja pegawai, kompetensi kepemimpinan dan budaya organisasi. Teknik pengambilan sampel menggunakan multistage sampling. Tahap pertama memilih populasi sasaran dengan teknik purposive samping. Populasi yang dipilih adalah pegawai bergolongan II dan III karena golongan IV tergolong pegawai yang memegang jabatan struktural. Tahap kedua adalah menentukan besarnya ukuran sampel dengan menggunakan acuan Slovin (J ohny Manairongsong, 2013: 140) rumusnya sebagai berikut:

$$
\mathrm{n}=\frac{\mathrm{N}}{1+N \alpha^{2}}=\frac{383}{1+383(0,1)^{2}}=79
$$

dimana: $\mathrm{n}=$ ukuran sampel, $\mathrm{N}=$ ukuran populasi dan $\mathrm{a}=$ batas toleransi ketidaktelitian dalam persen ( $1 \%, 5 \%$ atau $10 \%)$.

Dengan menggunakan rumus di atas, diperoleh ukuran sampel sebesar 79 orang kemudian disebar dengan menggunakan teknik proporsional random sampling. Proporsi dan sebaran sampel pada setiap unit kerja menggunakan rumus: $\mathrm{i}=\frac{\mathrm{Ni}}{N} x n$ dimana: $\mathrm{Ni}=$ jumlah populasi dari setiap unit kerja, $\mathrm{N}=$ jumlah populasi seluruh unit kerja dan $\mathrm{n}=$ ukuran sampel. Adapun proporsi dan sebaran sampel sebagaimana terlihat pada Tabel 1.

Teknik pengumpulan data menggunakan instrumen berupa angket dengan tujuan untuk menilai variabel kinerja pegawai, kompetensi pimpinan dan budaya organisasi. Kinerja pegawai adalah suatu set perilaku pegawai dalam melakukan tugas dan hasil yang diperoleh dari tugas tersebut yang dinilai melalui 4 dimensi yaitu: (1) Kecepatan menangani tugas; (2) Ketepatan menyelesaikan tugas; (3) Jumlah tugas yang diselesaikan dan (4) Keadilan dalam menyelesaikan tugas.

Variabel kompetensi pimpinan berkaitan dengan perilaku kompeten pemimpin dalam mengelola organisasi yang dipimpinnya yang dinilai melalui 5 dimensi yaitu : (1) Kompetensi personal; (2) Kompetensi emosional; (3) Kompetensi fungsional; (4) Kompetensi entrepreneurial dan (5) Kompetensi dalam pengambilan keputusan. Variabel budaya organisasi adalah nilai-nilai yang dimiliki organisasi untuk mengarahkan pegawai berperilaku sesuai tujuan organisasi dinilai melalui 5 dimensi yaitu: (1) Disiplin kerja; (2) Kreatif; (3) Inovatif; (4) Kerjasama dan (5) Kejujuran. Berdasarkan dimensi tersebut kemudian diturunkan pertanyaan-pertanyaan untuk menilai kinerja pegawai, kompetensi pimpinan dan budaya organisasi.

Tabel 1

Proporsi dan Sebaran Sampel di Setiap Unit Kerja

\begin{tabular}{|c|c|c|c|c|c|c|c|}
\hline \multirow[t]{2}{*}{ No } & \multirow[t]{2}{*}{ Unit Kerja } & \multicolumn{3}{|c|}{$\begin{array}{c}\text { Populasi menurut } \\
\text { Golongan }\end{array}$} & \multicolumn{3}{|c|}{$\begin{array}{c}\text { Proporsi dan Sebaran } \\
\text { Sampel menurut golongan }\end{array}$} \\
\hline & & II & III & $\mathbf{J} \mathbf{m l}$ & II & III & $\mathbf{J} \mathbf{m l}$ \\
\hline 1 & Kantor Pusat & 41 & 113 & 154 & 9 & 23 & 32 \\
\hline 2 & Fakultas Teknik & 7 & 19 & 26 & 2 & 4 & 6 \\
\hline 3 & Fakultas Bahasa dan Seni & 3 & 18 & 21 & 1 & 4 & 5 \\
\hline 4 & Fakultaas Ekonomi & 8 & 6 & 14 & 2 & - & 2 \\
\hline 5 & Fakultas IImu Keolahragaan & 5 & 15 & 20 & 1 & 3 & 4 \\
\hline 6 & Fakulta IImu Pendididukan & 8 & 22 & 30 & 2 & 5 & 7 \\
\hline 7 & Fakultas IImu Sosial & 2 & 17 & 19 & - & 4 & 4 \\
\hline 8 & Fakultas MIPA & 4 & 16 & 20 & 1 & 4 & 4 \\
\hline 9 & Perpustakaan & 2 & 19 & 21 & - & 4 & 4 \\
\hline 10 & Lembaga Pengabdian Masy. & 2 & 8 & 10 & - & 2 & 2 \\
\hline 11 & Lembaga Penelitian & 3 & 9 & 12 & 1 & 2 & 3 \\
\hline 12 & LP2AI & 3 & 2 & 5 & & - & - \\
\hline 13 & Program Pascasarjana & 6 & 16 & 22 & 1 & 4 & 5 \\
\hline 14 & Pusat Komputer & 1 & 8 & 9 & - & - & - \\
\hline & & 95 & 288 & 383 & 20 & 59 & 79 \\
\hline
\end{tabular}


Angket menggunakan skala likert dengan 5 pilihan jawaban. Untuk mendapakan kualitas data dari instrumen telah dilakukan uji validitas dan reliabilitas (terlampir). Analisis uji validitas menggunakan Korelasi Product Moment dan uji reliabilitas menggunakan uji Alpha Cronbach. Kriteria yang digunakan untuk menguji kesahihan (validitas) dilakukan sebagai berikut: Jika $r$-hitung $>r$-tabel pada $\alpha=0,05$ butir item dianggap sahih (valid) dan Jika r-hitung $\leq$ r-tabel pada $\alpha=0,05$ butir item dianggap tidak sahih. Hasil uji coba untuk variabel kinerja pegawai terdapat dua item pernyataan yang tidak valid yakni item nomor 7 dan item nomor 11. Tetapi menurut Sugiyono, (2006:116) syarat minimum suatu item dianggap valid apabila nilai $r \geq 0,30$ sedangkan item no. 7 koefisien $r=0,464$ dan item no. 11 koefisien $r=0,511$. Dengan mengacu pada kriteria ini, maka item no. 7 dan 11 juga tergolong valid. Dengan memertimbangan kedua item tersebut mendekati valid jika menggunakan kriteria lebih kecil dari alpha 0,05 $(a=0,05)$ maka kedua item yang tidak valid tersebut diperbaiki pernyataannya sesuai dengan indikator yang sesuai untuk itu, sehingga semua item (12 item) pada variabel kinerja pegawai digunakan untuk menjaring data.

Uji coba validitas variabel kompetensi pimpinan hasilnya terdapat 1 item yakni item no 15 yang tidak valid dan I item yang tidak valid dari variabel budaya organisasi yakni item no 13. Item-item tersebut diperbaiki pertanyaannya sehingga jumlah item yang diedarkan untuk menjaring data kompetensi pimpinan adalah 16 item dan budaya organisasi 16 item. Hasil uji reliabilitas instrumen variabel kinerja pegawai yakni $\mathrm{Ca}=0.760>0.70$ ), kompetensi pimpinan hasilnya $\mathrm{Ca}=0.769>0.70$ dan budaya organisasi hasilnya $\mathrm{Ca}=0.763>0.70$. Jika koefisien alpha Cronbach $(\mathrm{Ca})$ lebih besar atau sama dengan $0,70(\mathrm{Ca} \geq 0,70)$ maka instrument memiliki reliabilitas yang memadai.

Teknik analisis yang digunakan dalam penelitian ini adalah analisis jalur atau Path analysis bertujuan untuk menguji seberapa besar pengaruh langsung (kompetensi pimpinan) dan pengaruh tidak langsung (budaya organisasi) terhadap kinerja pegawai. Analisis jalur atau Path analysis akan menguji seperangkat hipotesis kausal dan menginterpretasikan hubungan tersebut (langsung atau tidak langsung).

\section{Hasil Penelitian dan Pembahasan}

Untuk menguji pengaruh Kompetensi Kepemimpinan, Budaya Organisasi dan Kinerja Pegawai telah diedarkan angket kepada 79 pegawai di Universitas Negeri Manado. Data hasil penelitian dideskripsikan pada Tabel 2. Hasil perhitungan data pada Tabel 2 menunjukkan bahwa untuk variabel Kompetensi Kepemimpinan (X1) di Universitas Negeri Manado, diperoleh hasil yakni skor maksimum sebesar 70.00 , skor minimum sebesar 53.00, rentang sebesar 17.00. dan rata-rata sebesar 62.0253 . Selanjutnya untuk variabel Budaya Organisasi (X2) diperoleh

Tabel 2

Deskripsi Data

\begin{tabular}{|c|c|c|c|c|c|c|}
\hline & $\mathrm{N}$ & Range & Minimum & Maximum & \multicolumn{2}{|c|}{ Mean } \\
\hline & Statistic & Statistic & Statistic & Statistic & Statistic & Std. Error \\
\hline $\mathrm{X} 1$ & 79 & 17.00 & 53.00 & 70.00 & 62.0253 & .47048 \\
\hline $\mathrm{X} 2$ & 79 & 16.00 & 55.00 & 71.00 & 63.2532 & .42689 \\
\hline $\mathrm{Y}$ & 79 & 23.00 & 35.00 & 58.00 & 49.3544 & .63824 \\
\hline $\begin{array}{c}\text { Valid N } \\
\text { (listwise) }\end{array}$ & 79 & & & & & \\
\hline
\end{tabular}

Tabel 3

Dekomposisi Pengaruh Antar Variabel

\begin{tabular}{|c|c|c|c|}
\hline \multirow{2}{*}{$\begin{array}{c}\text { Koefisien } \\
\text { Kausal }\end{array}$} & \multicolumn{2}{|c|}{ Pengaruh } & \multirow{2}{*}{ Total Pengaruh } \\
\cline { 2 - 3 } & Langsung & $\begin{array}{c}\text { Tidak Langsung } \\
\text { Melalui : }\end{array}$ & 0,736 \\
\hline $\mathrm{p}_{1 \times 1}$ & 0,451 & $\mathrm{X}_{2}=0,375 ;$ & 0,643 \\
\hline $\mathrm{P}_{21}$ & 0,798 & - & 0, \\
\hline
\end{tabular}


hasil, yakni skor maksimum sebesar 71.00 , skor minimum sebesar 55.00, rentang sebesar 16.00.sedangkan rata-rata sebesar 63.2532, dan untuk variabel Kinerja Pegawai (Y) diperoleh hasil, yakni skor maksimum sebesar 58.00, skor minimum sebesar 35.00 , rentang sebesar 23.00 sedangkan rata-rata sebesar 49.3544. Tahap selanjutnya adalah melakukan uji regresi dengan model Path Analysis sebagaimana terlihat pada Tabel 3.

Berdasarkan hasil analisis, model hasil penelitian terlihat pada Gambar berikut ini:

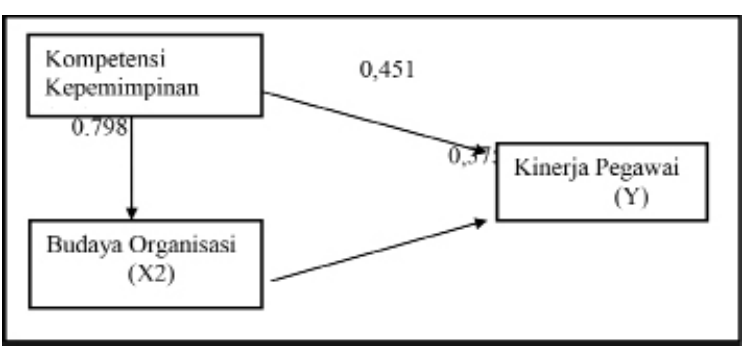

Gambar 1 : Model Hasil Penelitian

\section{Pengaruh Kompetensi Kepemimpi- nan terhadap Kinerja Pegawai}

Hasil analisis dengan menggunakan regresi model Path analysis memperlihatkan bahwa variabel kompetensi kepemimpinan (X1) berpengaruh langsung terhadap kinerja pegawai $(Y)$ pada $\rho_{1} X_{1}=0,451$. Temuan ini memberi pengertian bahwa variasi tinggi rendahnya kinerja pegawai dipengaruhi oleh kompetensi pemimpin. Hasil penelitian ini sejalan dengan konsep yang disampaikan Richard L Hughes, Robert C. Ginnett dan Gordon J. Curphy (2009:371), yang menjelaskan bahwa ada hubungan antara kepemimpinan, kepuasan dan kinerja.

Kebutuhan akan kompetensi pemimpin menjadi sangat urgen bagi sebuah perguruan tinggi untuk menjawab kebutuhan internal organisasi tetapi juga untuk mengadaptasikan diri dengan tuntutan eksternal. Lebih luas lagi Michael Zwell (2000: 9) menjelaskan 3 kompetensi yang mendukung kesuseksesan suatu organisasi yaitu The competence of its leadership, the competence of its employees, the degree to which the corporate culture fosters and maximizes competence.

Manajemen perguruan tinggi akan semakin baik bila pemimpinya memiliki kompetensi. Milan Pagon, Emanuel Banutai, Uroš Bizjak (2008:4) mendeskripsikan berbagai kompetensi kepemimpinan yang diperlukan untuk membangun manajemen yang sukses, yaitu:
1) Cognitive competencies include: divergent thinking, critical thinking, creativity, problem solving, strategic thinking, analytical skills, and numerical abilities, etc;

2) Functional competencies include: language and communication skills, technological skills (IT, media etc.), multicultural competencies (knowledge of a general and other cultures, foreign languages, etc. ), learning abilities and personal development, career planning skills, managerial skills and decision skill, etc.

3) Personal and social competencies include: self-direction, interpersonal skills, team works kills, compassion, integrity, mobilizing skills, personal and social values, and Ethical dimensions.

Studi terbaru tentang kepemimpinan memusatkan pada kompetensi pemimpin yang mencakup keterampilan, pengetahuan, sikap dan karakteristik personal yang akan menghasilkan kinerja superior. Mc Shane and Von Glinow (2010: 364) mengatakan bahwa kompetensi pemimpin mengindikasikan leadership potential not leadership performance. Menurutnya, ada 8 karakteristik kompetensi pemimpin yaitu:

(1) Personality: The leader's higher levels of extroversion (outgoing, talkative, sociable and assertive) and conscientiousness (careful, dependable, and self-disciplined);

(2) Self-concepts: The leader's self-beliefs and positive self-evaluation about his or her own leadership skills and ability to achieve objectives;

(3) Drive: The leader's inner motivation tu purpose goals;

(4) Integrity: The leader's truthfulness and tendency to translate words into deeds;

(5) Leadership motivation: The leaders's need for socialized power to accomplish team or organizational goals;

(6) Knowledge of the business: The leader's tacit and explicit knowledge about the company's environment, enabling the leader to make more intuitive decisions;

(7) Cognitive and practical intelligence: The leader's above-average cognitive ability to process information (cognitive intelligence) and ability to solve real-word problems by adapting to, shaping, or selecting appropriate environments (practical intelligence);

(8) Emotional intelligence: The leaders's ability to monitor his or her own and others emotions, discriminate among them, and use the information to guide his or her thoughs and actions.

Perbaikan kinerja pegawai di Universitas Negeri Manado secara berkelanjutan memerlukan perhatian dan dukungan kompetensi pemimpin dalam hal ini kompetensi personal, kompetensi emosional, kompetensi fungsional, kompetensi entrepreneurial dan kompetensi dalam pengambilan keputusan. Kuatnya kompetensi kepemimpinan memengaruhi kinerja pegawai karena secara fungsional 
pimpinan bertugas untuk menggerakkan perilaku kerja bawahannya agar kinerja pegawai mengarah pada pencapaian visi, misi dan tujuan organisasi.

\section{Pengaruh Budaya Organisasi terhadap Kinerja Pegawai}

Hasil penelitian menunjukkan bahwa variabel budaya organisasi berpengaruh langsung terhadap variabel kinerja pegawai artinya bahwa variasi tinggi rendahnya kinerja pegawai dipengaruhi oleh budaya organisasi. Temuan ini menjadi prediktor yang valid dan dapat diandalkan untuk meningkatkan kinerja pegawai.

Hasil penelitian ini mendukung penelitian Mohammad Jasim U, Rumana H.L dan Saad Md. (2013: 63-77) yang melakukan penelitian pada sektor Telekomunikasi Grameenphone di Bangladesh dengan merekomendasikan bahwa budaya organisasi secara signifikan memengaruhi kinerja pegawai dan produktivitas. Temuan ini juga sejalan dengan pandangan Stephen Robbins dan Timothy A. Judge (2011 : 575) menegaskan bahwa kuat lemahnya budaya organisasi memberi pengaruh terhadap kinerja dan kepuasan pegawai. Emmanuel Ogbonna and Lloyd C. Harris (2000 :766788) menyimpulkan berbagai pandangan dari seperti Kennedy (1982); Denison (1990); Kotter and Heskett (1992); Ouchi (1981); Pascale and Athos (1981); Peters and Waterman (1982) bahwa kinerja dipengaruhi oleh tingkat dimana nilai organisasi itu dimiliki oleh semua anggota dalam organisasi.

Kekuatan budaya organisasi memberi impact pada kinerja juga direkomendasikan oleh Schermerhorn, et al (2011: 366) dengan mengutip pendapat Ali Danisman, C. R Hinnings, T.Slack (2006) bahwa perbedaan budaya memberi impact utama pada kinerja organisasi dan kualitas kerja. Kinerja menjadi prediktor variabel budaya organisasi sebagaimana studi dari Alharbi Mohammad \& Alyahya Mohammed (2013) yang merekomendasikan bahwa ada, impact antara budaya organisasi dengan Kinerja pada institusi pendidikan. Satu hal penting bagi pimpinan dalam menciptakan dan mengelola budaya organisasi menurut Richard Daft (2010: 79-84) adalah mempertemukan dengan tujuan strategis organisasi sebab budaya organisasi diakui oleh berbagai ahli secara significant memberi impact bagi kinerja.

Studi lain yang dilakukan Marcoulides
\& Heck (1993: 209-225), Mohammad J.U, Rumana H. L, Saad Md (2013: 73-77) menjelaskan bahwa berbagai studi telah mengindikasikan hubungan antara budaya organisasi dan kinerja seperti:

\begin{abstract}
Magee (2002) beragumen bahwa that organizational culture is inherently connected to organizational practices; therefore organizational performance is conditional on organizational culture. Hellriegel \& Slocum (2009) menjelaskan bahwa organizational culture can enhance performance in a large scale if it can be understood that what sustains a culture. Some theoretical models assert that the effective human resource system of an organization is based onsupporting values and then these systems, in turn, create a positive impact on employee attitudes and behavior, which facilitate organization's performance (Ferris et al., 1998). Mercer and Bilson (1985) also point out the correlation between organizational culture and employees' performance; and this employees' performance then translated into organizational outcomes such as customer satisfaction (Schmidt, Shull, and Schmitt, 2001).
\end{abstract}

Setiap organisasi memiliki budaya organisasi yang menjadi pendorong untuk meningkatkan kinerja. Budaya organisasi menurut Sedarmayanti (2009: 75) adalah sebuah keyakinan, sikap dan nilai yang umumnya dimiliki, yang timbul dalam organisasi. Pola nilai, norma, keyakinan, sikap dan asumsi ini mungkin tidak diungkapkan tetapi akan membentuk cara orang berperilaku dan melakukan sesuatu.

Suatu organisasi memiliki budaya organisasi yang baik, menurut Denison and Misra (1995: 204-223) tercermin pada: 1) Involvement culture; 2) Consistency culture; 3) Adaptability culture; 4) mission culture. Budaya organisasi, menurut Robbins and Judge (2011: 554-575) berkenaan dengan a system of shared meaning heald by members that distinguished the organization from other organization. Menurutnya, budaya organisasi selain dapat meningkatkan kinerja pegawai juga dapat meningkatan kepuasan kerja.

Budaya organisasi pada perguruan tinggi melekat pada nilai-nilai yang dimiliki organisasi seperti disiplin kerja saat masuk kantor dan pulang kerja, disiplin dalam menyelesaikan pekerjaan, kreativitas kerja, budaya inovatif, kemampuan bekerjasama dan memiliki nilai-nilai kejujuran yang terinternalisasi pada setiap diri pegawai. Budaya organisasi akan menjadi penuntun 
berperilaku oleh semua sivitas akademika di perguruan tinggi sehingga dengan demikian budaya organisasi menjadi penggerak untuk menghasilkan budaya kinerja tinggi.

\section{Kompetensi Pemimpin, Budaya Organisasi dan Kinerja Pegawai}

Hasil penelitian menunjukkan bahwa terdapat pengaruh tidak langsung variabel kompetensi kepemimpinani $\left(X_{1}\right)$ terhadap kinerja Pegawai $(Y)$ melalui budaya organisasi $\left(X_{2}\right)$ sebesar 0,736 . Hal ini berarti bahwa peningkatan kinerja pegawai di Universitas Negeri Manado selain ditentukan oleh kompetensi kepemimpinan, namun akan semakin kuat pengaruhnya jika melalui budaya organisasi. Dengan demikian secara total, kinerja pegawai ditentukan oleh kompetensi kepemimpinan dan budaya organisasi baik secara langsung maupun tidak langsung di Universitas Negeri Manado.

Penelitian ini sejalan dengan penelitian yang dilakukan Muhammad Iskandar Hamzah dkk (2013: 270-285) mengenai efek dari kompetensi kepemimpinan terhadap prestasi kerja karyawan yang dimoderasi oleh variabel budaya organisasi. Penelitian yang telah dilakukan pada 530 responden di Universitas Utama Malaysia memberi kesimpulan terdapat pengaruh kompetensi kepemimpinan terhadap prestasi kerja karyawan yang dimoderasi oleh variabel budaya organisasi. Temuan yang sama dikemukakan Emmanuel Ogbonna and Lloyd C. Harris (2000: 766788) dengan mengungkapkan bahwa gaya kepemimpinan berpengaruh terhadap kinerja yang dimediasi oleh budaya organisasi.

Kinerja tinggi seharusnya menjadi budaya dari setiap pegawai. Menurut Colquitt, LePine and Wesson (2011: 35), kinerja seseorang berkait erat dengan pekerja yang baik atau good performer. Seseorang yang memiliki kinerja yang baik berkait dengan pertanyaan, "apa yang harus dilakukan oleh pekerja yang baik." Perilaku yang berkinerja baik menurut Stephen Robbins and Timothy A. Judge (2011: 599), terlihat pada:

(1) Task performance: Performing the duties and responsibilities that contribute to the production of a good or service or to administrative tasks. This includes most of the tasks in a conventional job description;

(2) Citizenship: Actions that contribute to the psychological environment of the organization, sucs as helping others when not required, supporting organizational objectives, treating co-workers with respect, making constructive suggestions, and saying posiative things about the workplace; (3) Counterproductive: Actions that actively damage the organization. These behaviors include stealing, damaging company property, behaving aggressively toward coworkeers, and avoidable absences.

Kinerja pegawai akan semakin menjadi lebih baik bila pereguruan tinggi memiliki budaya organisasi. Budaya organisasi tercermin pada keinginan bersama untuk mencapai misi dan tujuan organisasi , sebagaimana disampaikan oleh Richard Daft (2010: 84) bahwa budaya organisasi adalah

a culture based a solid organizational mission or purpose that uses shared adaptive values to guide decisions and business practices and to encourage indivual employee ownership of both bottom line results and the organization's cultural backbone.

Pandangan yang tidak jauh berbeda dikemukan Fakhar Shahzad, dkk (2012: 975985) dengan mengutip beberapa pendapat seperti Schein (1990) yang mengkaji budaya organisasi dengan mengatakan bahwa the concept of organizational culture also makes available a base for determination the differentiation that may survive in-between the organizations that are doing business in the same national culture; Stewart (2010) mengatakan bahwa that organization's norms and values have a strong affect on all of those who are attached with the organization. It is considered by him that norms are invisible but if the organizations want to improve the performance of the employees and profitability, norms are places first to look. Hodgetts and Luthans (2003) mengemukakan beberapa karakteristik dari budaya organisasi yaitu:

(1) Norms are measured by things like as amount of work done and also the level of cooperationbetween management and employees of the organization; (2) Clearly rules are defined for employee's behavior associated to the productivity, intergroup cooperation and customer relationship. (3) Observed behavioral regularities, as illustrate common language and formal procedures; (4) Coordination and integration between the organizational units for the purpose of improvement in efficiency to works, quality and speed of designing, manufacturing the products and services.

Berbagai argumen ini melihat bahwa budaya organisasi berkait dengan nilai dan norma yang dimiliki organisasi. Demikian juga Colquitt, LePine and Wesson (2011: 35) menjelaskan

job performance is formally defined as the value of the set of employee behaviors that contribute, either positively or negatively, to organizational goal accomplishment.

Bagi Universitas Negeri Manado, 
perbaikan dan peningkatan kinerja pegawai menjadi sebuah kebutuhan yang memerlukan dukungan kompetensi kepemimpinan dan budaya organisasi. Penyelenggaraan perguruan tinggi yang efektif menuju misi Universitas Negeri Manado yaitu berkualitas, unggul dan diperhitungkan akan dapat diraih bila pemimpinnya memiliki kompetensi dalam kepemimpinan dan memiliki budaya organisasi yang kuat sehingga menuntun mereka berkinerja tinggi.

\section{Simpulan dan Saran}

Hasil penelitian menunjukkan bahwa secara total terdapat pengaruh antara kompetensi kepemimpinan dengan kinerja pegawai melalui budaya organisasi. Berkaitan dengan penelitian ini maka perbaikan dan peningkatan kinerja pegawai di Universitas Negeri Manado menjadi sebuah kebutuhan yang memerlukan dukungan kompetensi kepemimpinan dan budaya organisasi.

Penyelenggaraan perguruan tinggi yang efektif menuju misi Universitas Negeri Manado, yaitu berkualitas, unggul dan diperhitungkan akan dapat diraih bila pemimpinnya memiliki kompetensi dalam kepemimpinan dan juga memiliki budaya organisasi yang kuat, sehingga menuntun mereka berkinerja tinggi.

Bagi Universitas Negeri Manado memiliki pemimpin yang kompeten tetapi kurang dukungan budaya organisasi, tidak cukup kuat menggerakkan pegawai berkinerja tinggi. Dengan demikian, peningkatan kinerja pegawai selain ditentukan oleh kompetensi kepemimpinan seperti kompetensi personal, kompetensi emosional, kompetensi fungsional, kompetensi entrepreneurial dan kompetensi dalam pengambilan keputusan juga akan semakin kuat bila melalui budaya organisasi yang memiliki nilai-nilai disiplin kerja, kreatif, inovatif, kerjasama, dan kejujuran.

\section{Daftar Pustaka}

Aan Komariah. (2014). "Pengaruh Kepemimpinan Transformasional, I klim Sekolah, Kinerja Mengajar Guru terhadap Produktivitas Sekolah." Jurnal Mimbar, Vol.30, No1. pp.118-125

Amstrong, Michael. (2009). Amstrong's Handbook of Performance Management, $4^{\text {th }}$ edition, London and Philadelphina, Kogan Page.

Bastaman, Komir (2012), “Pengaruh I klim dan Kepuasan Komunikasi serta Komitmen terhadap Kinerja Pegawai," J urnal Mimbar, Vol. XXVIII, No. 1, pp. 93-102.

Bersin, J osh. (2007). The Role of Competencies in Driving Financial Performance, Bersin and Associates Research Report.

Colcuitt, J ason A., LePine J efferey dan Wesson Michael. (2011). Organizational Behavior: Improcving Performance and Commitment in the Work Place, Second Edition, Mc Graw-Hill International Edition.

Daft, Richard. (2010). New Eera Management, $9^{\text {th }}$ edition, South Western Engage Learning.

Denison, D. R., dan Mishra, A. K. (1995). "Toward a Theory of Organizational Culture and Effectiveness," Organization Science, pp. 204-223.

Hall, R. (1993). “A Framework Linking Intangible Resources and Capabilities to Sustainable Competitive Advantage, "Strategic Management Journal, 14(8), pp. 607-618.

Hughes R.L., Ginnett R.C., dan Curphy Gordon J. (2009). Leadership: Enhancing the Lessons of Experience, $6^{\text {th }}$ edition, Mc Graw-Hill International Edition.

Indrajit R.Eko dan Djokopranoto (2006). Manajemen Perguruan Tinggi Modern, Yogyakarta, CV Andi Offset.

Joko, N. H. (2005). “Urgensi pengembangan SDM berbasis Kompetensi," Jurnal Administrasi Bisnis, Vol. 1, No. 2, pp. 51-58.

Manairongsong, J ohny. (2013). “Metodologi Penelitian (Terapan Bidang Ekonomi dan Bisnis)," Surabaya, CV.R.A.De. Rozarie.

Marcoulides, George A dan Heck, Ronald, H. (1993). "Organizational Culture and Performance: Proposing and Testing a Model," Organization Science, Vol.4.No.2. pp. 209-225

Mohammad J.U, Rumana H.L \& Saad Md (2013). Impact of Organizational Culture on Employee Performance and Productivity: A Case Study of Telecommunication Sector in Bangladesh, International Journal of Business and Management, Vol. 8, No. 2, pp.63-77.

Muhammad, Iskandar H. dkk.( 2013). "Moderating effects of Organizational Culture on the Link between Leadership Competencies and J ob Role Performance, "Australian Journal of Basic and Applied Sciences, 7(10), pp. 270-285.

Muya, James Ng'ang'a dan Wesonga, Justus Nyongesa. (2012). "The Impact of Organisational Culture on Performance of Educational institutions," International 
TINNEKE E. M SUMUAL. Pengaruh Kompetensi Kepemimpinan Budaya Organisasi terhadap Kinerja Pegawai ...

Journal of Business and Social Science, Vol. 3 No. 8, pp. 2011-2017.

Ogbonna, Emmanuel. and Lloyd C. Harris. (2000). "Leadership Style, Organizational Culture and Performance: Empirical Evidence," The International J ournal of Human Resource Management No.11, pp. 766- 788.

Palan, P. (2007). Competency Management : Teknik Mengimplementasikan Manajemen SDM Berbasis untuk Meningkatkan Daya Saing Organisasi, terjemahan Octa Melia Jalaa, Jakarta : PPM.

Pagon, Milan., EmanuelBanutai dan UrošBizjak. (2008). Leadership CompetenciesforSuccessful Change Management, APreliminaryStudyReport, Slovenian Presidency of the Eu, www. dgaep.gov.pt

Robbins, Stephen P. dan Timothy, A. Judge. (2011). Organizational Behavior. Upper Saddle River. New Jersey: Prentice Hall.

Schermerhorn, et a.I (2011). Organizational Behavior, Eleventh Edition, International Student Version, John Wiley \& Sons (Asia), Pte, Ltd.

Sedarmayanti. (2009). Manajemen Sumberdaya Manusia: Reformasi Birokrasi dan Manajemen Pegawai Negeri Sipil, PT Refika Aditama. Bandung.

Shane, Mc and Von Glinow (2010). Organizational Behavior: Emerging
Knowledge and Practice for the Real World, Fifth edition, Mc-Graw-Hill International Edition.

Shahzad Fakhar, et al.(2012)."Impact of Organizational Culture on Organizational Performance: An Overview." Interdisciplinary J ournal of Contemporary Research in Business. Vol 3, No 9.pp.975985.

Wibowo. (2010). Manajemen Kinerja. Edisi ketiga. Jakarta: Rajawali Pers.

Zenger, J. dan Folkman, J. (2002). The extraordinary leader. New York: McGrawHill.

Zwell, Michael. (2000). Creating A Culture of Competence. New York: J ohn Wiley \& Sonc. Inc. 